\title{
СКРИНИНГ ПЕРСПЕКТИВНЫХ ШТАММОВ ДРОЖЖЕЙ ДЛЯ ПРОИЗВОДСТВА ХЕРЕСНЫХ ВИН С ИСПОЛЬЗОВАНИЕМ ГЕНЕТИЧЕСКИХ И ЭНОЛОГИЧЕСКИХ МАРКЕРОВ
}

\author{
С.А. КИШКОВСКАЯ1, Т.Н. ТАНАЩУК', Д.А. АВДАНИНА², М.А. ЭЛЬДАРОВ 2 ,

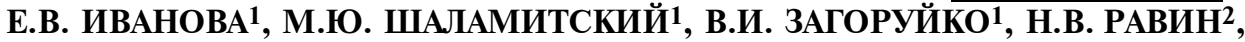
А.В. МАРДАНОВ 2 凶

\begin{abstract}
Хересные дрожжи - особая группа винодельческой микрофлоры, используемая при получении биологически выдержанных вин. В процессе биологической выдержки хересные дрожжи, культивируемые на поверхности сухих подспиртованных виноматериалов, переключают свой метаболизм с ферментативного на окислительный, что приводит к глубоким биохимическим изменениям вина с формированием неповторимых особенностей букета и аромата хересных вин. Генетические, биохимические и физиологические особенности хересных дрожжей, связанные с их адаптацией к специфическим условиям хересного виноделия, достаточно подробно изучены. Ранее использование методов сравнительного геномного анализа позволило нам идентифицировать ряд специфичных для хересных штаммов генетических маркеров, удобных для поиска штаммов, перспективных для получения вина типа Херес. В настоящей работе представлены результаты использования комбинированного подхода, основанного на первичном молекулярно-генетическом скрининге с последующим анализом физиолого-биохимических и энологических свойств для отбора перспективных для хересного виноделия штаммов в выборке из 47 штаммов из Коллекции микроорганизмов виноделия «Магарач» и 96 природных изолятов, выделенных из образцов винограда в разных климатических зонах в Республике Крым и в Ростовской области. На первом этапе отбор перспективных штаммов проводили на основании результатов генотипирования по наличию характерных для хересных штаммов аллелей локусов ITS, YDR379C-A и FLO11. По данным генотипирования у 41 штамма выявлен хересный аллель локуса ITS, у 41 штамма - хересный аллель гена $Y K L 281 C$, типичную для хересных штаммов делецию размером 111 нт в промоторе гена адгезина FLO11 обнаружили только у 12 штаммов. Всего 59 исследованных штаммов имели хересный аллель хотя бы одного из трех локусов. Дальнейшее изучение энологических свойств показало, что наличие хересного локуса ITS может служить маркером отбора штаммов с высокой окислительной способностыю. Образование пленки у большинства штаммов (11 образцов из 12) с хересным вариантом промотора гена FLO11 подтвердило основную роль гена этого адгезина в определении способности штаммов к поверхностному росту на виноматериале. Наиболее информативным оказалось использование маркера $Y D R 379 C$ - $A$. Из 12 штаммов, для которых определено наличие только этого хересного локуса, у трех коллекционных и двух природных штаммов (I-133, I-492, I-616, № 49, № 78) отмечали наличие всех хересных характеристик. Образование сплошной пленки с воспроизводимостью 100 \% наблюдали у двух коллекционных штаммов из этой группы - I-133 и I-492. Девять штаммов (75\%) синтезировали альдегиды в количестве свыше 100 мг/л, шесть штаммов (50\%) образовывали пленку с разной степенью формирования от островков на поверхности до сплошного роста и воспроизводимостью пленки от 33 до $100 \%$. Альдегидный тон в аромате и окисленность во вкусе определены для 58 \% образцов. Анализ энологических свойств шести штаммов, имеющих три хересных локуса, показал, что все они на поверхности сброженного сусла образовывали сплошную пленку в оптимальные сроки и пять штаммов синтезировали альдегиды при спиртовом брожении свыше 100 мг/л. Дегустация лабораторных образцов сброженного сусла выявила наличие хересных тонов в аромате и вкусе. Эти штаммы по результатам генотипирования и энологическим хересным характеристикам оказались близки к контрольному штамму I-329. В итоге по результатам проведенного скрининга и производственной проверки коллекционный штамм I-271 может быть рекомендован для хересования виноматериалов из сорта винограда Алиготе, традиционно используемого для этих целей, а также купажных виноматериалов из новых для хересных вин сортов винограда Ркацители и Совиньон зеленый, что открывает перспективу создания новых марок этого типа вина. Таким образом, проведенное исследование показало, что при первичном отборе новых хересных штаммов дрожжей $S$. cerevisiae их тестирование по генетическим маркерам ITS, YDR379C-A и FLO11 позволяет быстро и достоверно выявить наиболее перспективные штаммы для технологии производства хересных вин. Из 143 штаммов винных дрожжей по результатам проведенного генотипирования с учетом энологии выявлен штамм I-271 с большими потенциалом хересования виноматериалов.
\end{abstract}

Ключевые слова: Saccharomyces cerevisiae, хересные дрожжи, ДНК-маркеры, хересные аллели, ITS, YDR379C-A, FLO11, виноделие, энологические свойства, образование пленки, синтез альдегидов, адгезины. 
Селекция штаммов винных дрожжей с учетом особенностей региональной сырьевой базы и приемов получения вин разной технологической направленности служит перспективным подходом при совершенствовании производства вин. При этом штамм дрожжей рассматривается как важный фактор регулируемого формирования вина определенного типа.

Современные достижения генетики, химии и биохимии позволяют более детально изучить многие вопросы микробиологии виноделия и на основе такой комплексной оценки определить новую методологию отбора ценных штаммов дрожжей, используемых в винодельческой промышленности. Это дает возможность значительно расширить коллекционный генетический фонд штаммов дрожжей для виноделия и получить новые научнопрактические знания об их свойствах.

Рассматриваемая концепция наиболее актуальна для дрожжей, применяемых для получения вина типа Херес. Эти дрожжи, относящиеся к виду Saccharomyces cerevisiae (1-3), формируют на поверхности вина пленку и в результате окислительного метаболизма образуют продукты, придающие вину характерный хересный тон. В настоящее время исследования этой специфической группы штаммов $S$. cerevisiae активно развиваются, что в большой степени определено особенностью их практического использования (46). При разработке современных биотехнологий получения вин типа Херес для однозначной диагностики хересных дрожжей $S$. cerevisiae как в процессе искусственного отбора, так и для контроля производственных популяций неоспоримо значение молекулярно-генетических исследований.

В ранних работах для исследования генетического разнообразия и филогении хересных штаммов использовали данные анализа полиморфизма мтДНК (7), микросателлитный анализ (8), сравнительную геномную гибридизацию (9), изучение полиморфизма ряда локусов. Так, анализ локуса ITS1 методом ПДРФ (полиморфизм длин рестрикционных фрагментов, restriction fragment length polymorphism, RFLP) позволяет различать винные, испанские и французские хересные дрожжи $(8,10)$. Для большинства испанских штаммов характерна делеция размером 111 нт в промоторе гена FLO11, приводящая к усилению экспрессии этого адгезина и формированию более плотной пленки (11).

Бурный прогресс геномных исследований открыл новые возможности для расширения представлений об организации, эволюции и функционировании генома хересных дрожжей. В наших исследованиях и работах других авторов методами сравнительной геномики были обнаружены многочисленные специфические для хересных дрожжей гены и аллели генов, контролирующих различные пути метаболизма, транспорта, биогенеза клеточной стенки, стрессоустойчивости $(12,13)$, потенциально связанные с адаптацией хересных штаммов к специфическим условиям биологической выдержки. Исследования в области сравнительной геномики важны для понимания происхождения хересных штаммов и закономерностей их эволюции (14-16) и позволяют разработать удобные генетические маркеры для определения стратегий направленного отбора новых хересных штаммов дрожжей $S$. cerevisiae $(17,18)$. Полногеномный анализ винных и хересных дрожжей выявил у них различие в последовательности гена $Y D R 379 C-A(17,18)$.

Необходимо отметить, что в практике отечественного виноделия до сих пор применялись исключительно классические методы селекции винных штаммов, основанные на длительном и трудоемком многократном чередовании этапов мутаганеза и селекции.

В представляемой работе впервые показано, что тестирование изо- 
лятов $S$. cerevisiae по генетическим маркерам ITS, YDR379C-A и FLO11 позволяет быстро и достоверно выявить штаммы, наиболее перспективные для технологии производства хересных вин.

Целью исследований был многоступенчатый отбор новых штаммов дрожжей Saccharomyces cerevisiae для производства вин типа Херес пленочным способом с использованием молекулярно-генетических маркеров в сочетании с энологическими характеристиками.

Методика. Для изучения отобрали 143 штамма дрожжей рода Saccharomyces - 96 природных изолятов, выделенных из образцов винограда в разных климатических зонах в Республике Крым и в Ростовской области, для которых результаты генотипирования и некоторые энологические свойства были описаны нами ранее (17), и 47 штаммов из коллекции микроорганизмов виноделия «Магарач» (КМВ «Магарач»), не рекомендованных для производства хереса. В качестве эталонного использовали коллекционный штамм I-329, который применяется для производства вина типа Херес (19). Среды и режимы культивирования выбирали в соответствии с требованиями и рекомендациями по приготовлению вин типа Херес $(20,21)$.

Генотипирование штаммов по ITS, FLO11 и YDR379C-Ac маркерам проводили по методике, описанной нами ранее (17).

Для получения препаратов ДНК промытые и лиофильно высушенные клетки дрожжевых штаммов (30-50 мг) инкубировали в 500 мкл лизирующего буфера, содержащего SDS (0,1\%), Triton X-100 (1\%), протеиназу K (100 ед/мл, «Merck», Германия), в течение 20 мин при $65{ }^{\circ} \mathrm{C}$, затем экстрагировали нуклеиновые кислоты смесью фенола с хлороформом (1:1) и осаждали этанолом. Осадок растворяли в ТЕ буфере $(\mathrm{pH} 8,0)$.

Для молекулярно-генетической идентификации и отнесения образцов к винным или хересным штаммам дрожжей использовали метод ПДРФанализа (Restriction fragment length polymorphism, RFLP) ПЦР-фрагментов участков повтора рДНК, включающего два внутренних транскрибируемых спейсера ITS1 и ITS2 и ген 5,8S рРНК (8). Для ПЦР использовали праймеры Its1 5'-TCCGTAGGTGAACCTGCGG-3' и Its4 5'-TCCTCCGCTTATTGATATGC-3' (8). Режим ПЦР: $96^{\circ} \mathrm{C}-40$ c, $55^{\circ} \mathrm{C}-40$ c, $72{ }^{\circ} \mathrm{C}-40$ с $(30$ циклов). Здесь и далее использовали амплификатор Mastercycler personal («Еppendorf», Германия) и GoTaq® Flexi DNA полимеразу по протоколу производителя («Promega», США). Полученные фрагменты обрабатывали рестриктазой HaeIII («NEB», Великобритания), и после анализа электрофореграмм (1,5 \% агароза LE2, «Lonza», Швейцария; маркер молекулярных масс GeneRuler 1 kb DNA Ladder, «Thermo Fisher Scientific», США) относили штаммы к винным или к хересным. Для винных штаммов S. cerevisiae характерно образование фрагментов размером 311, 230, 172 и 128 п.н., для хересных - 311, 230, 148 и 129 п.н.

При анализе полиморфизма промотора гена FLO11 штаммы, несущие полноразмерный и укороченный (с делецией размером 111 нт) варианты промотора гена FLO11, выявляли методом ПЦР-анализа с праймерами Flo11D.REV (5'-TTTGGGCGACATTTTCTTGT-3') и Flo11D.FOR (5'-CCACGGGTGAGATTTGTTCT-3') (11). Условия ПЦР: $96{ }^{\circ} \mathrm{C}-40$ c, $51{ }^{\circ} \mathrm{C}-$ $40 \mathrm{c}, 72{ }^{\circ} \mathrm{C}-40$ с (30 циклов). Регистрировали образование фрагментов размером около 400 нт или 300 нт, характерных соответственно для дикого и хересного аллелей гена FLO11 (11).

Для обнаружения штаммов с полиморфными вариантами гена $Y D R 379 C$ - $A$ применяли ПДРФ-анализ ПЦР-фрагментов этого гена, полученных с праймерами F_sdh6 (5'-TCGCGTCAACTTGTTTTGAG-3') и R_sdh6 (5'-ATTCGTCAGTTCAGGGTGTGA-3'). Условия ПЦР: $96{ }^{\circ} \mathrm{C}-$ 
$40 \mathrm{c}, 52{ }^{\circ} \mathrm{C}-40 \mathrm{c}, 72{ }^{\circ} \mathrm{C}-40 \mathrm{c}$ (30 циклов). Фрагменты, имеющие длину около 800 п.н., обрабатывали рестриктазой AfIIII («NEB», Великобритания) согласно протоколу фирмы-производителя (18). Выявляли рестрикты размером 450 п.н. и 350 п.н., характерные для хересных аллелей гена $Y D R 379 C-A$.

В лабораторных условиях для культивирования штаммов использовали одну партию сусла из винограда сорта Алиготе урожая 2018 года с массовой концентрацией сахаров 210 г/л и массовой концентрацией титруемых кислот 7,0 г/л (рН 3,2). Подготовку сусла проводили в соответствии с правилами, принятыми в виноделии (5). Культуры из коллекции пересевали при помощи микробиологической петли в пробирки с ватно-марлевыми пробками в пастеризованное виноградное сусло и инкубировали в термостате при температуре $26 \pm 0,5^{\circ} \mathrm{C}$. Готовность полученной дрожжевой разводки оценивали методом световой микроскопии по следующим показателям: число клеток не менее 80 млн/ $\mathrm{cm}^{3}$, почкующихся клеток не менее $30 \%$, мертвых - не более $2 \%$.

При выращивании дрожжевой пленки в лабораторных условиях в пастеризованное виноградное сусло вносили дрожжевую разводку в количестве $2 \%$. Брожение проводили при температуре $18 \pm 0,5{ }^{\circ} \mathrm{C}$. По окончании брожения (массовая концентрация сахаров не более 4 г/л), полученный виноматериал доспиртовали до 15,3 об.\% этилового спирта и оставляли при температуре $18 \pm 0,5^{\circ} \mathrm{C}$ до формирования на поверхности виноматериала складчатой светло-бежевой пленки и оценивали ее физиологическое состояние при микроскопировании (доля живых клеток не менее 50 \%).

Способность штаммов к образованию пленки определяли по скорости ее роста на поверхности сброженного сусла и на спиртованном (до 15,3 об.\%) виноматериале. В лабораторных условиях пастеризованное виноградное сусло сбраживали в склянках объемом 200 мл под ватно-марлевыми пробками при температуре $18 \pm 0,5{ }^{\circ} \mathrm{C}$, в условиях микровиноделия использовали свежеотжатое сусло, которое сбраживали в 3-литровых стеклянных бутылях под ватно-марлевыми пробками при $18 \pm 0,5$ вую разводку вносили в виноградное сусло в количестве $2 \%$ от объема. Рост на поверхности фиксировали ежесуточно после окончания спиртового брожения.

При лабораторной оценке спиртоустойчивости дрожжей пленку, выросшую в 3-литровых бутылях на поверхности сброженного виноградного сусла, наносили на поверхность спиртованного виноматериала. Рост пленки и ее состояние оценивали визуально и прямым микроскопированием (19).

Адаптацию дрожжей к концентрации спирта 15,3 об.\% проводили по методу Н.Ф. Саенко посредством последовательных частых пересевов пленки на виноматериал с постепенно повышающейся концентрацией спирта.

Апробацию штамма в производственных условиях (фермерское хозяйство А.Н. Чернявского, г. Евпатория, Республика Крым) проводили в трех дубовых бочках объемом по 500 л, заполненных на 2/3 виноматериалом. Использовали два купажных виноматериала из сортов винограда - Алиготе $50 \%+$ Совиньон зеленый $25 \%+$ Ркацители $25 \%$ (бочка № 1), Совиньон зеленый $50 \%+$ Ркацители 50 \% (бочка № 2), а также виноматериал из винограда сорта Алиготе (бочка № 3). Для пленкования виноматериалов использовали дрожжевую пленку, выращенную в лабораторных условиях на спиртованном до 15,3 об.\% виноматериале сорта Алиготе. Хорошо развитые молодые пленки после проверки физиологического состояния дрожжей аккуратно в равных количествах переносили на 30 \% поверхности содержимого бочек. Верхнее отверстие бочек закрывали ватно-марлевыми пробками. Температура в помещении в течение всего периода наблюдений под- 
держивалась на уровне $18 \pm 1^{\circ} \mathrm{C}$. В процессе выдержки виноматериалов под пленкой проводили систематический микробиологический контроль за состоянием пленки (внешний вид, доля живых клеток не менее $50 \%$, наличие посторонней микрофлоры) и накоплением альдегидов.

После 3 мес выдержки под сформированной пленкой из бочек отбирали образцы для исследования.

Массовую концентрацию летучих кислот в образцах определяли по ГОСТ 32001-2012 («Продукция алкогольная и сырье для ее производства». М., 2014), массовую концентрацию альдегидов - по ГОСТ 12280-75 («Вина, виноматериалы, коньячные и плодовые спирты». М., 2003), массовую концентрацию остаточных сахаров - по ГОСТ 13192-73 («Вина, виноматериалы и коньяки». М., 2005), объемную долю этилового спирта - по ГОСТ 320292013 («Продукция алкогольная и сырье для ее производства». М., 2014).

Органолептическую оценку образцов проводили методом, принятым в виноделии (17).

Статистический анализ данных проводили в программе Microsoft Excel. Bce эксперименты выполняли в трех биологических повторностях, аналитические измерения - в двух повторностях. Представлены средние $(M)$ и стандартные ошибки средних ( \pm SEM) при доверительной вероятности $\mathrm{P}=0,95$.

Результаты. Скрининг с целью выявления штаммов дрожжей $S$. cerevisiae для производства вин типа Херес пленочным способом проводили по разработанной схеме (рис. 1).

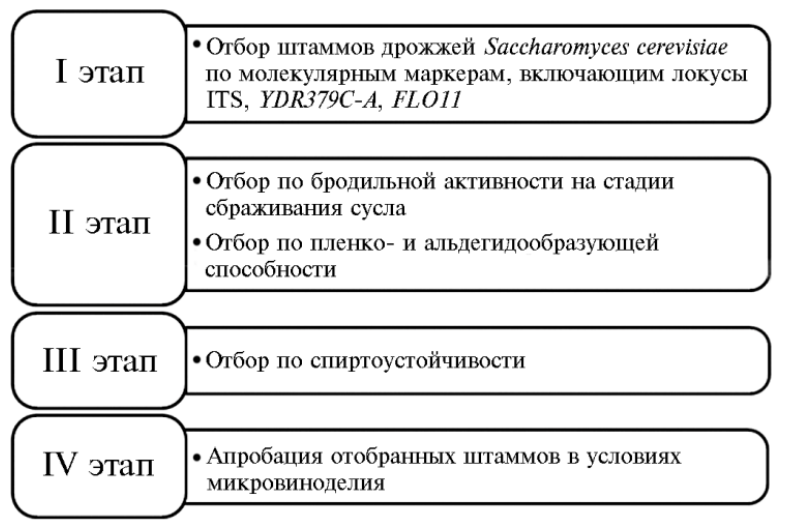

Рис. 1. Этапы отбора штаммов-кандидатов дрожжей Saccharomyces cerevisiae по генетическим и энологическим маркерам для производства вин типа Херес.

Генотипирование и энологические характеристики штаммов дрожжей Saccharomyces. Генотипирование 143 штаммов дрожжей на основе молекулярных маркеров, включающих локусы ITS, YDR379C-A и FLO11, показало, что 102 образца (71 \%) в локусе ITS имели последовательность, характерную для винных штаммов, 41 (29 \%) - для хересных. Специфический для хересных дрожжей аллель гена $Y D R 379 C$ - $A$ был выявлен у 41 штамма, а типичную для хересных штаммов делецию размером 111 нт в промоторе гена адгезина FLO11 обнаружили только у 12 штаммов. Всего 59 исследованных штаммов имели хересный аллель хотя бы по одному из трех локусов.

Выбор штаммов-кандидатов проводили на основе сравнения данных генотипирования и оценки специфических хересных энологических характеристик у лабораторных образцов сброженного виноградного сусла (табл. 1) - пленкообразующей и альдегидообразующей способности херес- 
ных дрожжей, а также придания винам свойств, характерных для типа Хеpec. Проведенные исследования физиолого-биохимических и технологических свойств промышленно ценных хересных штаммов из КМВ «Магарач» показали, что они образовывали пленку на поверхности сброженного сусла за период от 1 нед до 1 мес (19) и на этапе ферментации виноградного сусла синтезировали альдегиды в количестве от 132 до 352 мг/л. Для качественных столовых виноматериалов количество альдегидов, как правило, находится в пределах 20-100 мг/л и часто на уровнях, описываемых как сенсорный порог, - 40-100 мг/л (18). Во многом это определяется использованием штаммов дрожжей с низкой окислительной активностью. При выборе хересных штаммов-кандидатов мы учитывали их способность к синтезу альдегидов в количестве более 100 мг/л.

1. Представленность штаммов Saccharomyces cerevisiae по наличию хересных генетических и энологических маркеров в изученной выборке $(n=143$, коллекция микроорганизмов виноделия «Магарач», Республика Крым)

\begin{tabular}{|c|c|c|c|c|}
\hline \multirow{2}{*}{ Штамм } & \multirow{2}{*}{ Органолептическая характеристика } & \multirow{2}{*}{$\begin{array}{c}\text { МКА, мг/л } \\
(M \pm \text { SEM })\end{array}$} & \multicolumn{2}{|c|}{ Пленкообразование } \\
\hline & & & ПП & B \\
\hline \multicolumn{5}{|c|}{ Л окус ITS } \\
\hline $\mathrm{I}-31$ & Окисленность, солоноватость & $107,4 \pm 6,5$ & Пленка & $66 \%$ \\
\hline $\mathrm{I}-43$ & - & $103,4 \pm 6,3$ & - & \\
\hline $\mathrm{I}-53$ & Хересный тон, окисленность, солоноватость & $132,0 \pm 8,0$ & Кольцо & $66 \%$ \\
\hline I-214 & - & $114,4 \pm 6,9$ & - & \\
\hline I-307 & Хересный тон, окисленность & $160,6 \pm 9,7$ & - & \\
\hline I-440 & Хересный тон, окисленность, солоноватость & $148,7 \pm 9,0$ & - & \\
\hline I-471 & - & $178,2 \pm 10,8$ & - & \\
\hline I-527 & - & $123,2 \pm 7,5$ & - & \\
\hline I-630 & - & $92,4 \pm 5,6$ & - & \\
\hline I-651 & - & $171,6 \pm 10,4$ & - & \\
\hline I-653 & - & $123,2 \pm 7,5$ & - & \\
\hline № 19 & - & $71,3 \pm 4,3$ & - & \\
\hline № 28 & - & $73,0 \pm 4,4$ & - & \\
\hline № 74 & - & $37,8 \pm 2,3$ & - & \\
\hline № 75 & - & $128,5 \pm 7,8$ & - & \\
\hline № 76 & 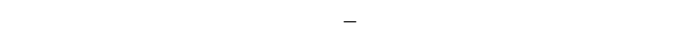 & $124,9 \pm 7,6$ & - & \\
\hline \multicolumn{5}{|c|}{ Л о к у с $Y D R 379 C-A$} \\
\hline I-133 & Хересный тон, окисленность, солоноватость & $171,6 \pm 10,4$ & Пленка & $100 \%$ \\
\hline I-308 & - & $114,4 \pm 6,9$ & - & \\
\hline I-492 & Хересный тон, окисленность, солоноватость & $180,4 \pm 10,9$ & Пленка & $100 \%$ \\
\hline I-616 & Хересный тон, окисленность & $184,8 \pm 11,2$ & Пленка & $66 \%$ \\
\hline № 45 & - & $84,5 \pm 5,1$ & - & \\
\hline № 49 & Слабый хересный тон, окисленность & $129,2 \pm 7,8$ & Пленка & $66 \%$ \\
\hline № 71 & - & $75,7 \pm 4,6$ & Пленка (островки) & $33 \%$ \\
\hline № 78 & Слабый хересный тон, окисленность & $154,9 \pm 9,4$ & Пленка (островки) & $33 \%$ \\
\hline № 79 & - & $91,5 \pm 5,5$ & - & \\
\hline № 97 & Окисленность & $202,4 \pm 12,3$ & - & \\
\hline № 108 & Окисленность & $183,0 \pm 11,1$ & - & \\
\hline \multirow{2}{*}{\multicolumn{5}{|c|}{ Л ок у с $F L O 11$}} \\
\hline & & & & \\
\hline № 52 & Хересный тон, окисленность & $140,3 \pm 8,5$ & Сплошная пленка & \\
\hline № 53 & _- & $34,3 \pm 2,1$ & Пленка (островки) & $100 \%$ \\
\hline № 90 & - & $74,5 \pm 4,5$ & - & $66 \%$ \\
\hline \multicolumn{5}{|c|}{ Л ок у с ы ITS + YDR379C- $A$} \\
\hline \multirow[t]{2}{*}{$\mathrm{I}-14$} & альдегидный тон в аромате, окисленность и солонова- & & & \\
\hline & тость во вкусе & $198,0 \pm 12,0$ & Пленка (кольцо) & $66 \%$ \\
\hline I-118 & Солоноватость и окисленность во вкусе & $162,8 \pm 9,9$ & Пленка (кольцо) & $66 \%$ \\
\hline I-137 & Альдегидный тон в аромате, окисленность во вкусе & $103,4 \pm 6,3$ & - & \\
\hline $\mathrm{I}-280$ & - & $149,6 \pm 9,1$ & - & \\
\hline $\mathrm{I}-310$ & Альдегидный тон в аромате, солоноватость во вкусе & $316,8 \pm 19,2$ & Пленка (островки) & $100 \%$ \\
\hline I-340 & Кислотность, легкая солоноватость во вкусе & $101,2 \pm 6,1$ & Пленка (кольцо) & $100 \%$ \\
\hline I-374 & - & $123,2 \pm 7,5$ & Пленка & $100 \%$ \\
\hline I-380 & Слабые хлебные тона в аромате & $167,2 \pm 10,1$ & Пленка & $100 \%$ \\
\hline $\mathrm{I}-448$ & Окисленность во вкусе & $123,2 \pm 7,5$ & Пленка (кольцо) & $33 \%$ \\
\hline I-515 & Солоноватость и окисленность во вкусе & $198,0 \pm 12,0$ & Пленка (островки) & $100 \%$ \\
\hline I-516 & - & $149,6 \pm 9,1$ & Пленка (кольцо) & $100 \%$ \\
\hline $\mathrm{I}-523$ & Солоноватость и окисленность во вкусе & $85,4 \pm 5,2$ & Пленка (островки) & $33 \%$ \\
\hline \multirow[t]{2}{*}{$\mathrm{I}-525$} & Хересный тон в аромате, солоноватость и окисленность & & & \\
\hline & во вкусе & $149,6 \pm 9,1$ & - & \\
\hline
\end{tabular}


Окисленность во вкусе

Пленка (островки) $33 \%$ Сплошная пленка $66 \%$ Пленка (островки) $33 \%$ Пленка (островки) $33 \%$ Пленка (кольцо) $66 \%$
№ 46

№ 54

№ 110

I-271

№ 3

№ 23

№ 111 Хересный тон в аромате и во вкусе

№ 113 Хересный тон в аромате и во вкусе во вкусе
Л о к у с ы $\mathrm{ITS}+$ FLO11

Нет штаммов

Л о к у с ы $Y D R 379 C-A+F L O 11$

Хересный тон в аромате, солоноватость и окисленность

$109,7 \pm 6,7$ Пленка (кольцо) $33 \%$

I-329 Хересный тон, окисленность, солоноватость

Кон т р ол в

$148,7 \pm 9,0$ Сплошная пленка $100 \%$ $253,4 \pm 15,4$ Пленка (кольцо) $100 \%$ о к у с ы ITS + YDR379C-A+FLO11

$343,2 \pm 20,8$ Сплошная пленка $66 \%$ $65,9 \pm 4,0$ Сплошная пленка $100 \%$ $105,6 \pm 6,4$ Сплошная пленка $100 \%$ $283,4 \pm 17,2$ Сплошная пленка $100 \%$ $279,8 \pm 17,0$ Сплошная пленка $100 \%$ $176,0 \pm 10,7$ Сплошная пленка $100 \%$

П р и м е ч н и е. МКА - массовая конщентращия альдегидов, ПП - наличие пленки на поверхности, В - воспроизводимость. Прочерки означают отсутствие признака.

Мы показали, что для 16 штаммов, имеющих только хересный маркер ITS, характерна высокая частота образцов (75 \%) с активным альдегидообразованием и низкая частота тех (13\%), которые проявили способность к поверхностному росту с надежностью его воспроизведения $66 \%$ в виде кольца у стенок склянки (коллекционный штамм I-53) до сплошного роста (коллекционный штамм I-31). Органолептическая оценка лабораторных образцов виноматериалов выявила альдегидный тон в аромате и окисленность во вкусе у четырех коллекционных штаммов (I-31, I-53, I-307, I-440), для которых отмечено образование альдегидов в концентрации 107,4-160,6 мг/л.

Исследование образцов на наличие хересного аллеля только локуса FLO11 выявило три природных штамма (№№ 52, 53, 90), из которых два (№ № 52, 53) образовывали пленку. Для одного природного штамма (№ 52) отмечали все энологические хересные характеристики - образование сплошной пленки с воспроизводимостью $100 \%$, образование альдегидов в количестве 140,3 г/л, альдегидный тон в аромате и окисленность во вкусе.

Наиболее информативным оказался маркер $Y D R 379 C-A$. Из 12 штаммов, для которых мы определили наличие только этого хересного локуса, у трех коллекционных и двух природных штаммов (I-133, I-492, I-616, № 49, № 78) проявились все хересные характеристики. Из них образование сплошной пленки с воспроизводимостью $100 \%$ наблюдали у двух коллекционных штаммов (I-133 и I-492). Девять штаммов (75 \%) синтезировали альдегиды в количестве свыше 100 мг/л, 6 штаммов (50 \%) образовывали пленку с разной степенью сформированности (от островков на поверхности до сплошного роста) и воспроизводимостью пленки от $33 \%$ до $100 \%$. Альдегидный тон в аромате и окисленность во вкусе были характерны для $58 \%$ образцов.

В группе с двумя хересными локусами - ITS и YDR379C-A (19 штаммов) или YDR379C-A и FLO11 (3 штамма) число штаммов с энологическими хересными характеристиками возрастало. Из них два штамма (коллекционный I-380 и природный № 54) формировали сплошную пленку с воспроизводимостью $100 \%$ и синтезировали альдегиды при спиртовом брожении в количестве 167,2-148,7 г/л с проявленим альдегидного тона в аромате и окисленности во вкусе.

Анализ энологических свойств шести штаммов (I-271, №№ 3, 23, 
$109,111,113)$ имеющих три хересных локуса, показал, что все они на поверхности сброженного сусла образовывали сплошную пленку в оптимальные сроки, а пять штаммов синтезировали альдегиды при спиртовом брожении (более 100 мг/л). Дегустация лабораторных образцов сброженного сусла выявила хересные тона в аромате и вкусе. Указанные штаммы по результатам генотипирования и энологическим хересным характеристикам близки к контрольному коллекционному штамму I-329.

Проведенное нами исследование показало, что наличие у штаммов дрожжей S. cerevisiae хересного локуса ITS может служить маркером отбора штаммов с высокой окислительной способностью. Образование пленки у большинства штаммов (11 штаммов из 12) с геном FLO11, непосредственно отвечающим за ее формирование, подтвердило основную роль этого гена при отборе штаммов, способных к поверхностному росту на виноматериале. Наличие локуса $Y D R 379 C$ - $A$ может служить маркером отбора штаммов по нескольким хересным характеристикам - высокой окислительной активности и способности к поверхностному росту. Маркер $Y D R 379 C-A$ также позволяет идентифицировать хересные штаммы, которые по результатам ITS-типирования относятся к винным.

Таким образом, на первом этапе отбор перспективных штаммов для производства вин типа Херес можно рекомендовать по результатам генотипирования при наличии у них хересных аллелей в трех локусах - ITS, $Y D R 379 C-A$ и FLO11. На этом этапе для технологических испытаний мы отобрали шесть образцов - I-271 (коллекционный промышленный штамм), №№ 3, 23, 109, 111 и 113 (природные штаммы).

Энологическая характеристика штаммов на стадии приготовления виноматериалов в условиях микровиноделия. Исследования проводили с тремя штаммами - I-271, № 3 и № 23. Штаммы № 3 и № 23 были отобраны нами на основании ранее проведенного исследования (17). Проверка штаммов на стадии ферментации виноградного сусла в условиях микровиноделия показала, что виноматериалы, приготовленные с их использованием, соответствовали всем требованиям, предъявляемым к виноматерилам для хересования. Штаммы незначительно различались по бродильной активности и способности к синтезу летучих кислот. Они в оптимальные для виноделия сроки сбродили сахара с образованием 12,5-13,1 об.\% спирта, при этом количество остаточных сахаров не превышало допустимую норму и составляло 1,2-2,5 г/л. Последний показатель мы рассматривали как основной на этом этапе отбора, поскольку низкая бродильная активность, связанная с неполным выбраживанием сахаров виноградного сусла, может служить одним из факторов, отрицательно влияющих на формирование пленки (28). Массовая концентрация летучих кислот находилась в пределах 0,10-0,57 г/л, альдегидов - составила 65,9-105,6 мг/л, во вкусе и аромате отсутствовали посторонние тона.

Наиболее важные признаки хересных дрожжей при селекции - способность к быстрому размножению с образованием пленки на поверхности вина, содержащего 15-16 об.\% спирта, а также способность к синтезу альдегидов, количество которых при отборе готового хересного виноматериала из-под пленки должно составлять не менее 350 мг/л (21). Ацетальдегид, на который приходится до 90 \% всех альдегидов вина, - важный компонент хересованных вин, главным образом влияющий на их ароматические характеристики (22-24). Скорость формирования пленки на поверхности виноматериала и накопление альдегидов при биологической выдержке во многом зависят от применяемого штамма. В основном формирование хересной пленки происходит в течение срока от 3 до 30 сут в зависимости от штамма 
и спиртуозности среды (25), а концентрация ацетальдегида в процессе хересования в виноматериале может достигать 1000 мг/л (23, 26-28).

По скорости поверхностного роста исследованные нами штаммы дрожжей (№ 3, № 23, I-271, I-329) были близки. Так, поверхностный рост начинался в течение 8-10 сут с момента окончания брожения, а формирование пленки по всей поверхности происходило на 13-16-е сут. По количеству альдегидов и органолептической характеристике виноматериалы, выдержанные под пленкой, отвечали требованиям, предъявляемым к биологически выдержанным виноматериалам (табл. 2).

2. Характеристика перспективных штаммов Saccharomyces cerevisiae с тремя хересными локусами (ITS $+Y D R 379 C-A+F L O 11)$ по пленко- и альдегидообразованию в условиях микровиноделия (коллекция микроорганизмов виноделия «Магарач», Республика Крым)

\begin{tabular}{|c|c|c|c|c|c|}
\hline \multirow[b]{2}{*}{ Штамм } & \multicolumn{2}{|c|}{ Рост пленки, сут } & \multirow[b]{2}{*}{ Пленка через 1 мес } & \multirow{2}{*}{$\begin{array}{l}\text { Альдегиды, } \\
\text { мг/л } \\
(M \pm \mathrm{SEM})\end{array}$} & \multirow[b]{2}{*}{$\begin{array}{l}\text { Дегустационная } \\
\text { характеристика }\end{array}$} \\
\hline & \begin{tabular}{|l|} 
начало \\
(островки)
\end{tabular} & $\begin{array}{l}\text { окончание (на } \\
\text { всей поверхности) }\end{array}$ & & & \\
\hline $\mathrm{I}-271$ & 9 & 15 & $\begin{array}{l}\text { Сплошная, тонкая, эла- } \\
\text { стичная }\end{array}$ & $426,8 \pm 5,7$ & $\begin{array}{l}\text { Хересный тон в аро- } \\
\text { мате и вкусе }\end{array}$ \\
\hline № 3 & 9 & 16 & $\begin{array}{l}\text { Тонкая, неоднородная } \\
\text { по плотности, с просве- } \\
\text { тами, светло-бежевая }\end{array}$ & $492,9 \pm 7,7$ & $\begin{array}{l}\text { Слабый хересный } \\
\text { тон в аромате и } \\
\text { вкусе }\end{array}$ \\
\hline № 23 & 10 & 16 & $\begin{array}{l}\text { Сплошная, однородная, } \\
\text { светло-бежевая }\end{array}$ & $768,0 \pm 5,8$ & $\begin{array}{l}\text { Хересный тон в аро- } \\
\text { мате и вкусе }\end{array}$ \\
\hline I-329 & 8 & 15 & $\begin{array}{l}\text { Сформированная, склад- } \\
\text { чатая, темно-бежевая }\end{array}$ & $506,0 \pm 8,8$ & $\begin{array}{l}\text { Сильный хересный } \\
\text { тон в аромате и вкусе }\end{array}$ \\
\hline
\end{tabular}

С пиртовыносл ивость. Полученные дрожжевые пленки штаммов №№ 3, 23 и I-271, сформированные на поверхности сброженного сусла с концентрацией этанола 12,5-13,1 \%, при их переносе сразу на поверхность виноматериала с концентрацией этанола $16 \%$ показали резкое замедление роста с последующим отмиранием клеток. В дальнейшем мы применили метод Н.Ф. Саенко, которая при получении спиртоустойчивых штаммов хересных дрожжей постепенно адаптировала их к повышенным концентрациям спирта (26). Анализ показал (рис. 2), что коллекционный штамм I-271 хорошо адаптировался к высокой концентрации спирта и быстрее формировал пленку по всей поверхности виноматериала. Штаммы № 3 и № 23 при концентрации спирта 15,3 \% снизили ростовую активность и площадь покрытия поверхности пленки составила 70-80\%. У этих штаммов мы отмечали хорошее физиологическое состояние пленки (до 70 \% живых клеток), несмотря на снижение ростовой активности (27).

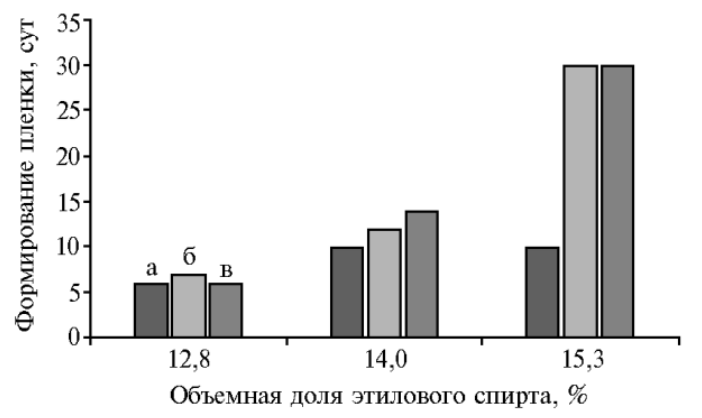

Рис. 2. Продолжительность формирования пленки у перспективных штаммов Saccharomyces cerevisiae с тремя хересными локусами $($ ITS + YDR379C-A + FLO11) в зависимости от спиртуозности виноматериала: а - коллекционный штамм I-271, б - природный штамм № 3, в - природный штамм № 23 (микровинодельческий опыт; коллекция микроорганизмов виноделия «Магарач», Республика Крым).

Коллекционный штамм I271 по спиртоустойчивости, формированию пленки, органолептической оценке, накоплению альдегидов, а также по физиологическому состоянию клеток пленки был близок к контрольному хересному штамму I-329.

Таким образом, для апробации в условиях производства мы отобрали коллекционный штамм I-271. Природные штаммы № 3 и № 23 также 
перспективны для дальнейшей селекции по энологическим показателям.

Апробация в производственных условиях. Опытные образцы вин типа Херес были приготовлены методом пленкования виноматериалов (28). По данным химических анализов скорости роста пленки, массовой концентрации альдегидов и по дегустационной оценке, все варианты купажей виноматериалов соответствовали типу хересного виноматериала, биологически выдержанного в течение $3 \mathrm{mec.}$

Полное зарастание пленки на поверхности виноматериалов прошло практически одновременно: в бочках № 1 и № 2 - на 12-е сут после пленкования, в бочке № 3 - на 10-е сут. Количество альдегидов в виноматериалах после 3-месячной выдержки под пленкой составило в первой бочке 618,4 мг/л, во второй $-506,0$ мг/л, в третьей $-537,7$ мг/л (погрешность измерения $5 \%$ ), что соответствовало требованиям технологической инструкции (21). Все опытные образцы виноматериалов были прозрачные, соломенного цвета, с чистым легким ароматом и хересными тонами в аромате и вкусе.

По результатам проведенного скрининга и производственной проверки коллекционный штамм I-271 может быть рекомендован для хересования виноматериалов из сорта винограда Алиготе, традиционно используемого для этих целей, а также купажных виноматериалов из новых для хересных вин сортов винограда Ркацители и Совиньон зеленый, что открывает перспективу создания новых марок этого вина.

Итак, проведенное исследование показало, что при первичном отборе хересных штаммов дрожжей Saccharomyces cerevisiae их тестирование по генетическим маркерам ITS, YDR379C-A и FLO11 позволяет быстро и достоверно выявить наиболее перспективные штаммы для технологии производства хересных вин. В результате благодаря проведенному генотипированию среди 143 штаммов винных дрожжей выявлен штамм № I-271 с большим потенциалом хересования виноматериалов (спиртоустойчивость, формирование сплошной, тонкой, эластичной пленки, хересный тон в аромате и вкусе).

\section{ЛИТЕРАТУРА}

1. Кудрявцев В.И. Систематика дрожжей. М., 1954.

2. Наумов Г.И. Дифференциация генофонда культурных дрожжей Saccharomyces: восемь групп культиваров. Доклады Академии наук СССР, 1989, 306(5): 1253-1255.

3. The yeasts: a taxonomic study /C.P. Kurtzman, J.W. Fell, T. Boekhout (eds.). Elsevier Science, 2010.

4. Benítez T., Rincón A.M., Codyn A.C. Yeasts used in biologically aged wines. In: Molecular wine microbiology /A.V. Carrascosa., R. Mucoz, R. González (eds.). Academic Press, San Diego, 2011: 51 54 (doi: 10.1016/B978-0-12-375021-1.10003-7).

5. Эльдаров М.А., Кишковская С.А., Танащук Т.Н., Марданов А.В. Геномика и биохимия винных штаммов дрожжей Saccharomyces cerevisiae. Усnехи биологической химии, 2016, 56: 155-196 (doi: 10.1134/S0006297916130046).

6. Наумов Г.И. Генетический полиморфизм хересных дрожжей Saccharomyces cerevisiae. Микробиология, 2017, 86(1): 25-38 (doi: 10.7868/S0026365616060161).

7. Castrejyn F., Codon A.C., Cuberto B., Benitez T. Acetaldehyde and ethanol are responsible for mitochondrial DNA (mtDNA) restriction fragment length polymorphism (RFLP) in flor yeasts. System. Appl. Microbiol., 2002, 25(3): $462-467$ (doi: 10.1078/0723-2020-00127).

8. Charpentier C., Colin A., Alais A., Legras J.-L. French Jura flor yeasts: Genotype and technological diversity. Antonie van Leeuwenhoek, 2009, 95(3): 263-273 (doi: 10.1007/s10482-0099309-8).

9. Legras J.-L., Erny C., Charpentier C. Population structure and comparative genome hybridization of European flor yeast reveal a unique group of Saccharomyces cerevisiae strains with few gene duplications in their genome. PLoS ONE, 2014, 9(10): e108089 (doi: 10.1371/journal.pone.0108089).

10. Esteve-Zarzoso B., Peris-Toran M.J., Garcia-Maiquez E., Uruburu F., Querol A. Yeast population dynamics during the fermentation and biological aging of sherry wines. Appl. Environ. Microbiol., 2001, 67(5): 2056-2061 (doi: 10.1128/AEM.67.5.2056-2061.2001). 
11. Fidalgo M., Barrales R.R., Ibeas J.I., Jimenez J. Adaptive evolution by mutations in the FLO11 gene. Proc. Natl. Acad. Sci USA., 2006, 103(30): 11228-1123 (doi: 10.1073/pnas.0601713103).

12. Coi A.L., Bigey F., Mallet S., Marsit S., Zara G., Gladieux P., Galeote V., Budroni M., Dequin S., Legras J.L. Genomic signatures of adaptation to wine biological ageing conditions in biofilm-forming flor yeasts. Mol. Ecol., 2017, 26(7): 2150-2166 (doi: 10.1111/mec.14053).

13. Eldarov M.A., Beletsky A.V., Tanashchuk T.N., Kishkovskaya S.A., Ravin N.V., Mardanov A.V. Whole-genome analysis of three yeast strains used for production of sherry-like wines revealed genetic traits specific to flor yeasts. Front. Microbiol., 2018, 9: 965-978 (doi: 10.3389/fmicb.2018.00965).

14. Legras J.-L., Moreno-Garcia J., Zara S., Zara G., Garcia-Martinez T., Mauricio J.S., Mannazzu I., Coi A.L., Zeidan M.B., Dequin S., Moreno J., Budroni M. Flor yeast: new perspectives beyond wine aging. Front. Microbiol., 2016, 7: 503-514 (doi: 10.3389/fmicb.2016.00503).

15. Legras J.-L., Galeote V., Bigey F., Camarasa C., Marsit S., Nidelet T., Sanches I., Couloux A., Gue J., Franco-Duarte R., Marcet-Houben M., Gabaldon T., Schuller D., Sampaio J.P., Dequin S. Adaptation of $S$. cerevisiae to fermented food environments reveals remarkable genome plasticity and the footprints of domestication. Mol. Biol. Evol., 2018, 35(7): 1712-1727 (doi: 10.1093/molbev/msy066).

16. David-Vaizant V., Alexandre H. Flor yeast diversity and dynamics in biologically aged wines. Front. Microbiol., 2018, 9: 2235-2251 (doi: 10.3389/fmicb.2018.02235).

17. Кишковская С.А., Танащук Т.Н., Шаламитский М.Ю., Загоруйко В.И., Ширяев М.И., Авданина Д.А., Эльдаров М.А., Равин Н.В., Марданов А.В. Природные штаммы дрожжей Saccharomyces cerevisiae, перспективные для производства вин типа Херес. Прикладная биохимия и микробиология, 2020, 56: 275-282 (doi: 10.31857/S055510992003006X).

18. Эльдаров М.А., Авданина Д.А., Шаламитский М.Ю., Иванова Е.В., Танащук Т.Н., Кишковская С.А., Равин Н.В., Марданов А.В. Полиморфизм генов гомеостаза железа и чувствительность к железу у хересных и винных штаммов Saccharomyces cerevisiae. Микробиология, 2019, 88(2): 217-223 (doi: 10.1134/S0026365619020034).

19. Кишковская С.А., Эльдаров М.А., Думина М.В., Танащук Т.Н., Равин Н.В., Марданов А.В. Генетическая и физиолого-биохимическая характеристика коллекции штаммов хересных дрожжей. Прикладная биохимия и микробиология, 2017, 3: 323-332 (doi: 10.7868/S0555109917030096).

20. Общие правила производства натуральных сухих вин. В сб.: Сборник основных правил, технологических инструкций и нормативных материалов по производству винодельческой продукии /Под ред. Н.Г. Саришвили. М., 1998: 21-25.

21. Технологическая инструкция по производству вина типа Херес. В сб.: Технологические правила виноделия /Под ред. Г.Г. Валуйко. Симферополь, 2006: 105-110.

22. Bakker J., Clarke R.J. Wine: flavour chemistry. 2nd Edition. Wiley-Blackwell, 2011.

23. Wine chemistry and biochemistry /M.V. Moreno-Arribas, M.C. Polo (eds.). Springer, 2009 (doi: 10.1007/978-0-387-74118-52).

24. Руссу Е.И. Качество и совершенствование технологии производства хересных вин. Кишинев, 1992.

25. Martínez P., Pérez Rodríguez L., Bénitez T. Factors which affect velum formation by flor yeasts isolated from sherry wine. Syst. Appl. Microbiol., 1997, 20: 154-157 (doi: 10.1016/S07232020(97)80060-4).

26. Саенко Н.Ф. О направленной изменчивости как методе получения спиртоустойчивых хересных дрожжей. В сб.: Вопросы микробиологии в виноделии и виноградарстве. М., 1952: $33-49$.

27. Ibeas J.I., Lozano I., Perdigones F., Jimenez J. Dynamics of flor yeast populations during the biological aging of sherry wines. Am. J. Enol. Vitic., 1997, 48(1): 75-79.

28. Martínez P., Rodríguez P.L., Benítez T. Velum formation by flor yeasts isolated from sherry wine. Am. J. Enol. Vitic., 1997, 48(1): 55-62.

1ФГБУН Всероссийский национальный научно-исследовательский институт виноградарства и виноделия «Магарач» РАН,

298600 Россия, Республика Крым, г. Ялта, ул. Кирова, 31, e-mail: microbiolog9@rambler.ru,28tnt@mail.ru,

lenochka_ivanova58@mail.ru,mhalamitskiy@yahoo.com, valya.yalta64@mail.ru;

2 Институт биоинженерии,

ФИЦ Фундаментальные основы биотехнологии РАН,

119071 Россия, г. Москва, Ленинский просп., 33, корп. 2,

e-mail: daria.avdanina@biengi.ac.ru, nravin@biengi.ac.ru,

mardanov@beingi.ac.ru $\bowtie$
Поступила в редакцию

21 октября 2020 года 


\title{
SCREENING FOR PROMISING YEAST STRAINS FOR SHERRY WINE PRODUCTION USING GENETIC AND ENOLOGICAL MARKERS
}

\author{
S.A. Kishkovskaial, T.N. Tanashchuk ${ }^{1}$, D.A. Avdanina ${ }^{2}$, M.A. Eldarov $^{2}$, E.V. Ivanova ${ }^{1}$, \\ M.Yu. Shalamitskiy', V.I. Zagoruiko', N.V. Ravin ${ }^{2}$, A.V. Mardanov ${ }^{凶}$
}

\begin{abstract}
${ }^{1}$ National Research Institute for Grape and Wine Magarach RAS, 31, ul. Kirova, Yalta, Republic of Crimea, 298600 Russia, e-mail microbiolog9@rambler.ru, 28tnt@mail.ru, lenochka_ivanova58@mail.ru, mhalamitskiy@yahoo.com, valya.yalta64@mail.ru;

2Institute of Bioengineering, Federal Research Center Fundamentals of Biotechnology RAS, 33/2, Leninskii prospect, Moscow, 119071 Russia, e-mail daria.avdanina@biengi.ac.ru, nravin@biengi.ac.ru, mardanov@beingi.ac.ru ( $₫$ cor-
\end{abstract} responding author)

ORCID:

Kishkovskaia S.A. orcid.org/0000-0002-1281-0612

Tanashchuk T.N. orcid.org/0000-0002-7847-1246

Avdanina D.A. orcid.org/0000-0003-1501-5865

Eldarov M.A. orcid.org/0000-0001-8328-2637

Ivanova E.V. orcid.org/0000-0002-1281-0612

The authors declare no conflict of interests

Received October 21, 2020

Shalamitskiy M.Yu. orcid.org/0000-0001-5888-6228

Zagoruiko V.I. orcid.org/0000-0001-7508-8383

Ravin N.V. orcid.org/0000-0002-1456-1832

Mardanov A.V. orcid.org/0000-0002-8245-8757

doi: 10.15389 /agrobiology.2021.3.537eng

\section{Abstract}

Flor yeast is a special group of wine-making microflora used in the production of biologically aged wines. In the process of biological aging, flor yeast, cultivated on the surface of dry, alcoholbased wine materials, switches its metabolism from enzymatic to oxidative, which leads to deep biochemical changes in the wine with the formation of unique features of the bouquet and aroma of sherry wines. Genetic, biochemical and physiological features of flor yeast associated with their adaptation to specific conditions of sherry winemaking have been studied in sufficient detail. Earlier, the use of comparative genomic analysis methods allowed us to identify a number of genetic markers specific for flor strains, convenient for searching for strains that are promising for producing sherrytype wines. This work presents the results of using a combined approach based on primary molecular genetic screening followed by analysis of physiological, biochemical and oenological properties for the selection of strains promising for sherry winemaking in a sample of 47 strains from the Magarach Winemaking Microorganism Collection and 96 natural isolates from samples of grapes in different climatic zones in the Republic of Crimea and in the Rostov region. At the first stage, the selection of promising strains was carried out on the basis of the results of genotyping by the presence of alleles of the loci ITS, YDR379C-A, and FLO11 characteristic of flor strains. According to the genotyping data, the flor allele of the ITS locus was identified in 41 strains, the flor allele of the $Y D R 379 C$ - $A$ gene was identified in 41 strains, and a deletion of $111 \mathrm{nt}$ in the promoter of the adhesin FLO11 gene, typical of flor strains, was found in only 12 strains. A total of 59 studied strains had the flor allele of at least one of the three loci. Further study of oenological properties showed that the presence of the ITS flor locus can serve as a marker for the selection of strains with high oxidative capacity. Film formation in most strains (11 samples out of 12) with a flor variant of the FLO11 gene promoter confirmed the main role of this adhesin gene in determining the ability of strains to surface growth on wine material. The most informative was the use of the $Y D R 379 C-A$ marker. Of the 12 strains for which the presence of only this flor locus was determined, three collection and two natural strains (I-133, I-492, I-616, No. 49, No. 78) showed the presence of all flor characteristics. The formation of a continuous film with a reproducibility of $100 \%$ was observed in two collection strains from this group - I-133 and I492. Nine strains (75\%) synthesized aldehydes in an amount exceeding $100 \mathrm{mg} / \mathrm{l}, 6$ strains $(50 \%)$ formed a film with varying degrees of formation from islands on the surface to continuous growth and film reproducibility from 33 to $100 \%$. Aldehyde aroma and oxidation taste were determined for $58 \%$ of the samples. Analysis of the oenological properties of six strains with three flor loci showed that all of them formed a continuous film on the surface of the fermented wort at optimal times, and five strains synthesized aldehydes during alcoholic fermentation above $100 \mathrm{mg} / \mathrm{l}$. Tasting laboratory samples of fermented wort revealed the presence of sherry tones in aroma and taste. According to the results of genotyping and oenological sherry characteristics, these strains were close to the control strain I-329. As a result, according to the results of the screening and production check, the collection strain I-271 can be recommended for sherrying wine materials from the Aligote grape variety, traditionally used for these purposes, as well as blended wine materials from the Rkatsiteli and Sauvignon green grape varieties, new for sherry wines, which opens up the prospect creation of new brands of this type of wine. Thus, the study showed that during the initial selection of new flor strains of $\mathrm{S}$. cerevisiae yeast, testing them for genetic markers ITS, YDR379C-A, and FLO11 allows you to quickly and reliably identify the most promising strains for the technology of sherry wine production. Of 143 strains of wine yeast, according to the results of genotyping, taking into account oenology, strain I-271 with great potential for sherrying wine materials was identified.

Keywords: Saccharomyces cerevisiae, flor yeast, DNA markers, flor alleles, ITS, YDR379CA, FLO11, winemaking, oenological properties, film formation, aldehyde synthesis, adhesins. 